\title{
Truffaut's Antoine Doinel films DVD collection
}

\author{
By Jan Uhde
}

\section{Fall 2003 Issue of KINEMA}

The impact of the DVD revolution goes far beyond the indisputable and conspicuous improvement of the image quality available on the new carrier. The implications - a kind of ripple effect - are profound. Access to a great variety of films, formerly restricted to inhabitants of large metropolises, has been significantly improved. Good movies neglected by the existing distribution and exhibition structures are now coming within reach of practically anyone who desires them. One can even enjoy films which would otherwise be accessible only to a handful of researchers in film archives and research institutes.

Restorations of old films offer a new perspective on the history of cinema: through these, viewers discover damaged, lost or censored image material; enjoy improved subtitles, upgraded musical scores. The DVD publishers are learning to observe aesthetic rules such as proper screen ratio which is often neglected by both the television broadcasters and videocassette producers.

One of the most recent contributions to quality home viewing is the new Criterion Collection edition of five films by François Truffaut - his famous Antoine Doinel "pentalogy," featuring Truffaut's alter ego, JeanPierre Léaud. The coffret (the box looks like a small suitcase) contains 400 Blows, the featurette Antoine and Collette, Stolen Kisses, Bed and Board and Love on the Run.

The collection's films are drawn from new digital transfers, using anamorphic widescreen format; there is a bounty of supporting material far beyond the customary "theatrical trailers:" Truffaut's 18-minute short Les mistons (The Mischief Makers, 1957), the 44-minute documentary Working with Francois Truffaut, several interviews, behind-the scenes-footage, archive newsreel footage, a 72-page illustrated booklet and other valuable material. The design of the individual DVD cases is simply beautiful - now one can see that even the small DVD cases can be a joy to look at, once the movie-watching is over.

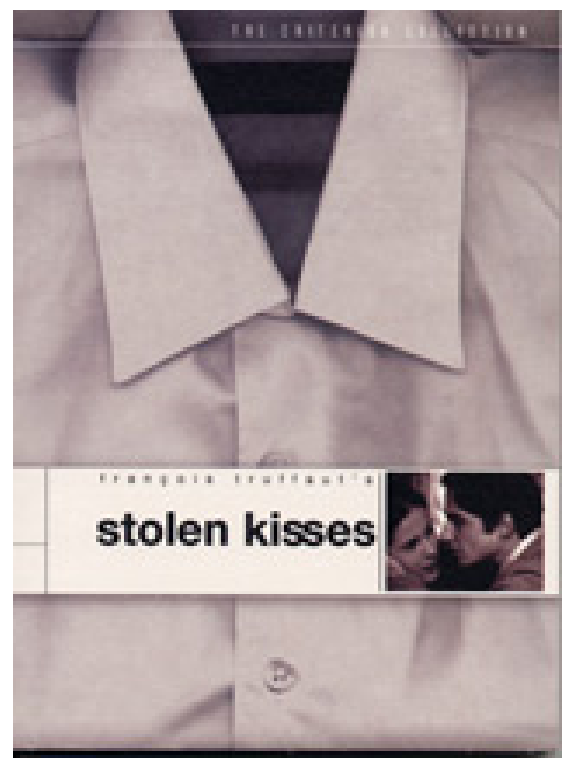

Figure 1:

\section{Author Information}

Jan UHDE is Professor Emer. (Film Studies) at the University of Waterloo, Ontario, Canada. Born in Brno, Czech Republic. Graduated (MA) from the Faculty of Arts, Masaryk University, Brno; PhD received at the 
University of Waterloo, Ontario, Canada. He taught at the University of Waterloo (1970-2012) where he founded a General and Honours BA program in Film Studies at the Department of Fine Arts.

Publications: Latent Images: Film in Singapore Second edition, with Yvonne Ng Uhde (Ridge Books, National University Press of Singapore, 2010); Latent Images: Film in Singapore, with Yvonne Ng Uhde (Oxford University Press, 2000); Latent Images: Film in Singapore CD-ROM (2003, co-author); Vision and Persistence: Twenty Years of the Ontario Film Institute (University of Waterloo Press, 1990) and Ontario Film Institute Programming Activities Index 1969-1989 (Toronto: Ontario Science Centre, 1990). He co-edited the Place in Space: Human Culture in Landscape (Proceedings from the Second International Conference of the Working Group "Culture and Landscape" of the International Association of Landscape Ecology, Pudoc Scientific Publishers, Wageningen, Holland, 1993). Jan Uhde has published articles and reviews in several countries (including Canada, USA, Germany, Italy), participated in international juries at film festivals and presented papers at international conferences in North America and Europe. In 1998/99, he was a visiting researcher at the School for Film and Media Studies, Ngee Ann Polytechnic, Singapore.

His professional and research interests focus on Singapore cinema; the identification and distancing mechanisms of the film viewer; the non-authored modifications and manipulation of films; and specific aspects of film history, including the Central European cinema.

He founded KINEMA in 1993. 